\title{
Massilia brevitalea sp. nov., a novel betaproteobacterium isolated from lysimeter soil
}

\author{
Correspondence \\ Jörg Overmann \\ j.overmann@Irz.uni-muenchen.de
}

\section{Delita Zul, ${ }^{1,2}$ Gerhard Wanner ${ }^{3}$ and Jörg Overmann ${ }^{1}$}

\author{
${ }^{1}$ Bereich Mikrobiologie, Department Biologie I, Ludwig-Maximilians-Universität München, \\ Maria-Ward-Straße 1a, D-80638 München, Germany \\ ${ }^{2}$ Department of Biology, Faculty of Mathematics and Natural Sciences, University of Riau, \\ Kampus Bina Widya Km. 12, 5 Simpang Baru, Pekanbaru, Indonesia \\ ${ }^{3}$ Bereich Botanik, Department Biologie I, Ludwig-Maximilians-Universität München, \\ Menzinger Straße 67, D-80638 München, Germany
}

\begin{abstract}
A Gram-negative, strictly aerobic bacterium, designated strain byr $23-80^{\top}$, was isolated from lysimeter soil by using a high-throughput cultivation technique. Cells of strain byr23-80 ${ }^{\top}$ were found to be short rods that multiplied by binary fission and were motile by means of a single polar flagellum. Occasionally, two to three polar or lateral flagella were observed. The optimum growth temperature was $15^{\circ} \mathrm{C}$ and the $\mathrm{pH}$ optimum was 7.0-7.5. The predominant cellular fatty acids were $\mathrm{C}_{16: 1} \omega 7 c(54.7 \%)$ and $\mathrm{C}_{16: 0}(21.4 \%)$. In addition, the diagnostic fatty acids $\mathrm{C}_{10: 0}$ $3-\mathrm{OH}$ and $\mathrm{C}_{12: 0} 2-\mathrm{OH}$ were detected. $\mathrm{Q}-8$ was the predominant respiratory quinone. The isolate was physiologically very versatile, using a wide range of sugars, organic acids and amino acids as single carbon and energy sources for growth. The $G+C$ content of the genomic DNA was $65.3 \mathrm{~mol} \%$. Phylogenetic analyses supported the assignment of strain byr23-80 ${ }^{\top}$ to the genus Massilia within the family Oxalobacteraceae of the class Betaproteobacteria. Within the genus, strain byr23-80 ${ }^{\top}$ was most closely related to Massilia aurea DSM $18055^{\top}$, with a $16 \mathrm{~S}$ rRNA gene sequence similarity of $98.3 \%$. However, DNA-DNA hybridization revealed a pairwise similarity for the genomic DNA of only $20.1 \%$ between strain byr23-80 ${ }^{\top}$ and strain DSM $18055^{\top}$. The novel isolate could be distinguished from the existing species Massilia timonae, Massilia dura, Massilia albidiflava, Massilia plicata, Massilia lutea and $M$. aurea by its significantly lower temperature optimum for growth and by the absence of gelatinase, $\alpha$-galactosidase and $\beta$-galactosidase activities. On the basis of these characteristics, strain byr23-80 $0^{\top}$ constitutes a novel species of the genus Massilia, for which the name Massilia brevitalea sp. nov. is proposed. The type strain is byr23-80 ${ }^{\top}\left(=\right.$ DSM $18925^{\top}=$ ATCC BAA $\left.-1465^{\top}\right)$.
\end{abstract}

The genus Massilia comprises the following six species: Massilia timonae (La Scola et al., 1998), Massilia dura, Massilia albidiflava, Massilia plicata, Massilia lutea (Zhang et al., 2006) and Massilia aurea (Gallego et al., 2006). M. timonae strains were isolated from human blood, cerebrospinal fluid and bone (La Scola et al., 1998; Lindquist et al., 2003). Bacteria of this species are straight rods that are motile by means of single polar flagellum or, more rarely, up to three polar or lateral flagella per cell. They are distinguishable from other aerobic, non-fermentative, Gram-negative rods on the basis of their 16S rRNA gene sequence, acid production from carbohydrates and positive reactions for catalase, oxidase, RNase, pectinase, chondroitinase, starch hydrolysis and aesculin hydrolysis. Other

Abbreviation: TEM, transmission electron microscopy.

The GenBank/EMBL/DDBJ accession number for the partial 16S rRNA gene sequence of strain byr23-80 ${ }^{\top}$ is EF546777. typical characteristics are the presence of $\mathrm{C}_{16: 0}, \mathrm{C}_{16: 1} \omega 7 c$, and $\mathrm{C}_{18: 1} \omega 7 \mathrm{c}$ as the predominant fatty acids and the presence of $\mathrm{C}_{10: 0} 3-\mathrm{OH}$ and $\mathrm{C}_{12: 0} 2-\mathrm{OH}$ as diagnostic cellular fatty acids (Lindquist et al., 2003). M. dura, M. albidiflava, $M$. plicata and $M$. lutea were recovered from farm soil contaminated with heavy metals and, with the exception of $M$. lutea, differed from $M$. timonae in their production of urease and their ability to reduce nitrate (Zhang et al., 2006). M. aurea was isolated from drinking water and differed from the other species by the absence of $\beta$-glucosidase and $\alpha$-galactosidase (Gallego et al., 2006). Additional unidentified members of the genus Massilia utilize glucose (Padmanabhan et al., 2003) and have the capacity to degrade phenanthrene (Bodour et al., 2003) or other aromatic compounds (Khammar et al., 2005).

Strain byr $23-80^{\mathrm{T}}$ was isolated during the investigation of bacterial communities in soil lysimeters (Zul et al., 2007). 
The high-throughput MicroDrop technique (Bruns et al., 2003) was employed to inoculate bacterial cells into microtitre plates containing soil solution equivalent (Angle et al., 1991), which was buffered at a $\mathrm{pH}$ of 7.0 using $10 \mathrm{mM}$ HEPES and supplemented with artificial root exudates, yeast extract $(0.01 \%, \mathrm{w} / \mathrm{v})$ and inducers, as described previously (Bruns et al., 2003; Zul et al., 2007). Cultures were incubated at $15{ }^{\circ} \mathrm{C}$ for 6 weeks. Bacterial strains were isolated by streaking liquid cultures onto the medium described above, solidified with gellan gum ( $8 \mathrm{~g} \mathrm{l}^{-1}$; Sigma-Aldrich Chemie). One of the cultured betaproteobacteria, strain byr $23-80^{\mathrm{T}}$, was selected for further characterization since it occurred in association with higher plants (Zul et al., 2007). Subsequent physiological, biochemical and phylogenetic characterization revealed that the isolate represents a novel member of the genus Massilia within the family Oxalobacteraceae of the order Burkholderiales.

The shape and colour of colonies was examined on agarsolidified HD medium ( $1: 10$ diluted; consisting of $0.05 \%$ casein peptone, $0.01 \%$ glucose and $0.025 \%$, w $/ v$, yeast extract) as well as on nutrient agar (Sigma). Colonies were pale white (young cultures) to yellowish (old cultures) on HD $(1: 10)$ agar plates and yellow on nutrient agar. Cells of strain byr $23-80^{\mathrm{T}}$ grown for $36 \mathrm{~h}$ in $\mathrm{HD}(1: 10)$ were short
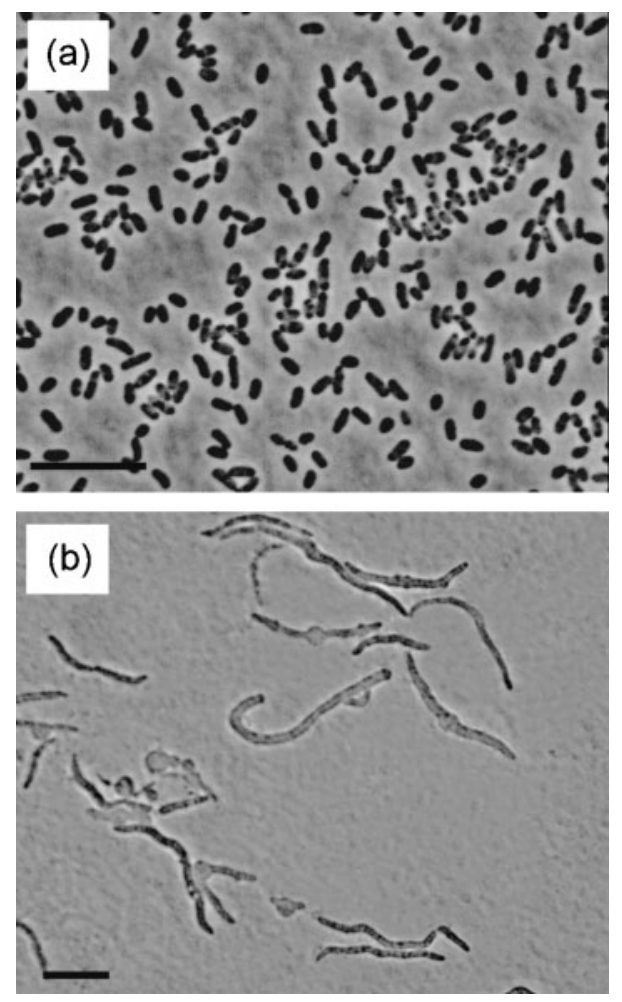

Fig. 1. (a) Phase-contrast photomicrograph of cells of strain byr23-80 $0^{\top}$ grown in $1: 10$-diluted $\mathrm{HD}$ medium at $15^{\circ} \mathrm{C}$ for $36 \mathrm{~h}$. (b) Morphology of cells grown in undiluted $\mathrm{HD}$ medium at $15{ }^{\circ} \mathrm{C}$ for 36 h. Bars, $10 \mu \mathrm{m}$. rods $1.5-2.0 \mu \mathrm{m}$ in length and $0.7-1.0 \mu \mathrm{m}$ in width (Fig. 1a); they divided by binary fission and were motile. In contrast, cells grown in undiluted HD medium became significantly elongated (up to $35 \mu \mathrm{m}$ ) and varied in shape (Fig. 1b). For scanning electron microscopy, drops of the sample were placed onto a glass slide, covered with a coverslip and rapidly frozen with liquid nitrogen. The cover-slip was removed with a razor blade and the cells were immediately fixed with $2.5 \%$ glutaraldehyde in $75 \mathrm{mM}$ cacodylate buffer ( $\mathrm{pH} 7.0$ ), post-fixed with osmium tetroxide, dehydrated in a graded series of acetone solutions, critical-point dried with liquid $\mathrm{CO}_{2}$, mounted on stubs and coated with $3 \mathrm{~nm}$ platinum with a magnetron sputter coater (BAE 121; Balzers). The specimens were examined with a field emission scanning electron microscope (S-4100; Hitachi) operated at $5 \mathrm{kV}$. Most cells exhibited a single polar flagellum (Fig. 2a). Occasionally, cells with two to three polar or lateral flagella were observed.

Cells stained Gram-negative, which was confirmed by transmission electron microscopy (TEM) of cells harvested in the exponential growth phase. Cells were fixed with $2.5 \%$ glutaraldehyde in $75 \mathrm{mM}$ sodium cacodylate and $2 \mathrm{mM} \mathrm{MgCl}_{2}$ ( $\mathrm{pH} \mathrm{7.0)}$ for $1 \mathrm{~h}$ at room temperature, rinsed several times in fixative buffer and post-fixed for $1 \mathrm{~h}$ with $1 \%$ osmium tetroxide in fixative buffer at room
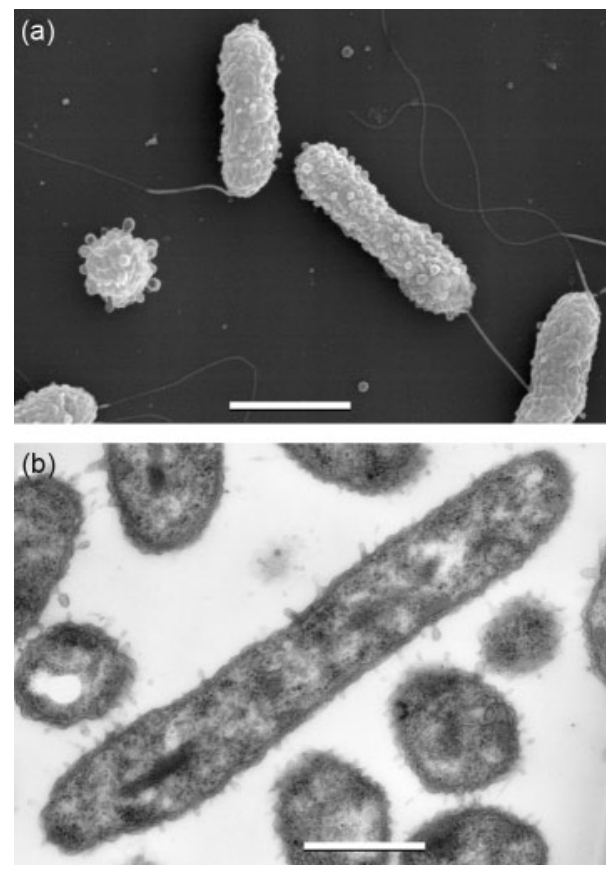

Fig. 2. (a) Scanning electron micrograph of cells of strain byr23-80 ${ }^{\top}$ showing the monopolar, monotrichous flagellation and numerous protuberances of the cell envelope. (b) Transmission electron micrograph of an ultrathin section of cells, showing the cell envelope, typical of Gram-negative bacteria, and the protuberances of the outer membrane. Bars, $1 \mu \mathrm{m}$ (a) and $500 \mathrm{~nm}$ (b). 
temperature. After two washing steps with distilled water, the cells were stained en bloc with $1 \%$ uranyl acetate in $20 \%$ acetone for $30 \mathrm{~min}$. Dehydration was performed with a graded acetone series. Samples were then infiltrated with, and then embedded in, Spurr's low-viscosity resin (Spurr, 1969); ultrathin sections (50 and $70 \mathrm{~nm}$ ) were cut with a diamond knife and mounted on uncoated copper grids. The sections were post-stained with aqueous lead citrate (100 mM, pH 13.0). All micrographs were taken with a TEM (EM 912; Zeiss) equipped with an integrated OMEGA energy filter operated in zero-loss mode. Investigations of exponentially growing cells confirmed the presence of an outer membrane, a thin murein layer and a cytoplasmic membrane (Fig. 2b). A striking feature of the cells was the presence of numerous protuberances of various sizes, formed by the outer membrane, over the entire cell surface (Fig. 2a, b).

Catalase and oxidase tests were performed as described by Lányí (1987) and revealed that strain byr $23-80^{\mathrm{T}}$ was oxidase-negative and weakly catalase-positive. The temperature range and the optimum temperature for growth in HD $(1: 10)$ medium were $4-30{ }^{\circ} \mathrm{C}$ and $15{ }^{\circ} \mathrm{C}$, respectively. While the temperature range for the novel strain was comparable with that of $M$. aurea, the optimum temperature for growth was unusual in that it was significantly lower than that of any recognized Massilia species (Table 1). Subsequent growth tests were therefore performed at $15{ }^{\circ} \mathrm{C}$. The $\mathrm{pH}$ range for growth was $6.0-10.0$, with an optimum value of 7.0-7.5. Salt tolerance was tested at $\mathrm{NaCl}$ concentrations between 0 and $10 \%(\mathrm{w} / \mathrm{v})$ and demonstrated that growth occured at concentrations $\leqslant 2 \% \mathrm{NaCl}$. Cells grew obligately aerobically and were capable of reducing $\mathrm{NO}_{3}^{-}$to $\mathrm{NO}_{2}^{-}$, as tested on nitrate broth containing $0.2 \% \mathrm{KNO}_{3}$ (Skerman, 1967). Hydrolysis of starch was tested on agar plates containing $1 \%(\mathrm{w} / \mathrm{v})$ peptone, $1 \%$ yeast extract and $0.5 \%$ soluble starch. Gelatinase production was determined on Luria-Bertani plates containing $3 \%(\mathrm{w} / \mathrm{v})$ gelatin. Hydrolysis of casein was examined on nutrient agar supplemented with $1.5 \%$ skim milk (Sigma). Milk coagulation and peptonization were tested on $10.0 \%(\mathrm{w} / \mathrm{v})$ litmus milk medium. These assays demonstrated that the cells were capable of hydrolysing starch and casein but not gelatin. The inability of strain byr $23-80^{\mathrm{T}}$ to hydrolyse gelatin was a feature that clearly distinguished it from all recognized species of the genus Massilia (Table 1). Additional enzyme activities were determined by employing API ZYM galleries (bioMérieux) according to the protocol of the manufacturer and with incubation of the assays at $15{ }^{\circ} \mathrm{C}$. Strain byr $23-80^{\mathrm{T}}$ gave strong positive reactions for acid phosphatase, leucine arylamidase and naphthol-AS-BI-phosphohydrolase. In contrast to all other Massilia species tested, however, the novel isolate did not exhibit $\alpha$-galactosidase or $\beta$ galactosidase activities. It also tested negative for arginine dihydrolase, ornithine decarboxylase and lysine decarboxylase activities. HD medium at a $1: 10$ dilution was used to analyse the methyl red and Voges-Proskauer reactions by adding methyl red and Barritt's reagents, respectively. Indole production was examined in tryptophan broth, with detection using the addition of Kovács reagent. Urease production was determined in media supplemented with $0.5 \%$ urea (Ederer et al., 1971) and $\mathrm{H}_{2} \mathrm{~S}$ production was tested on Kligler's iron agar (Difco). Cells of strain byr23$80^{\mathrm{T}}$ tested negative for the production of acetoin, indole and $\mathrm{H}_{2} \mathrm{~S}$ and did not exhibit urease activity.

Substrate utilization patterns were determined in microtitre plates filled with basal soil solution equivalent medium supplemented with individual carbon substrates (Gich \& Overmann, 2006). Substrate utilization was evaluated by repeatedly measuring the optical density at $620 \mathrm{~nm}$ in each well using a microtitre plate reader (Tecan) over an incubation period of 6 weeks. Cellobiose, Derythrose, L-erythrulose, D-galactose, glucose, glucose 1phosphate, glucose 6-phosphate, maltose and $N$-acetylglucosamine were utilized as sole carbon and energy sources. In addition, the strain grew on 19 of 36 organic acids and on 13 of 22 amino acids tested, but did not utilize any of the eight alcohols tested (Table 1). The strain was also able to utilize $\alpha$-ketoisocaproate, $\alpha$-ketoglutarate, $\alpha$-ketovalerate, Casamino acids, yeast extract and peptone.

Antibiotic susceptibilities were determined by using the disc-diffusion plate method, using HD $(1: 10)$ agar plates inoculated with strain byr $23-80^{\mathrm{T}}$. The 16 antibiotics and antibiotic combinations tested were as follows ( $\mu$ g per disc, unless otherwise stated): amikacin (30), ampicillin (25), bacitracin (10 U per disc), carbenicillin (100), chloramphenicol (30), erythromycin (15), gentamicin (10), kanamycin monosulfate (30), novobiocin (5), penicillin G (10), rifampicin (5), streptomycin sulfate (30), sulfamethoxazole + trimethoprim (23.7 and 1.2), tetracycline (30), tobramycin (10) and vancomycin (30). Resistance was observed towards bacitracin, carbenicillin, chloramphenicol, erythromycin, gentamicin, novobiocin, and penicillin G.

The results of the chemotaxonomic analyses are given in Table 2 and the species description. For these determinations, cells were grown under optimum conditions on HD $(1: 10)$ at $15{ }^{\circ} \mathrm{C}$ for $36 \mathrm{~h}$. Respiratory lipoquinones and polar lipids were extracted from, respectively, 2 and $0.1 \mathrm{~g}$ freeze-dried cell material and analysed according to Tindall (1990a, b). For the fatty acid analysis, a $40 \mathrm{mg}$ (wet weight) sample of cells was scraped from Petri dishes and the fatty acid methyl esters were extracted according to the method of Miller (1982) and Kuykendall et al. (1988), using the Microbial Identification System (MIDI). These analyses were carried out by the Identification Services of the Deutsche Sammlung von Mikroorganismen und Zellkulturen (Braunschweig, Germany). The major cellular fatty acids were $\mathrm{C}_{16: 1} \omega 7 c(54.7 \%)$ and $\mathrm{C}_{16: 0}(21.4 \%)$. Similarly to members of the genus Massilia (Lindquist et al., 2003), cells of strain byr23-80 $0^{\mathrm{T}}$ contained $\mathrm{C}_{10: 0} 3-\mathrm{OH}$ and $\mathrm{C}_{12: 0} 2-\mathrm{OH}$ as the diagnostic cellular fatty acids. The main quinone component was Q-8. 
Table 1. Main morphological, biochemical and physiological characteristics of strain byr $23-80^{\top}$ in comparison with those of species within the genus Massilia

Strains: 1, byr23-80 ${ }^{\mathrm{T}}$; 2, M. timonae CIP $105350^{\mathrm{T}}$ (Lindquist et al., 2003; La Scola et al., 1998); 3, M. dura CCTCC AB 204070 ${ }^{\mathrm{T}}$; 4, M. albidiflava CCTCC AB $204071^{\mathrm{T}}$; 5, M. plicata CCTCC AB 204072 ${ }^{\mathrm{T}}$; 6. M. lutea CCTCC AB $204073^{\mathrm{T}}$ (data for strains 3-6 from Zhang et al., 2006); 7, M. aurea DSM 18055 ${ }^{\mathrm{T}}$ (Gallego et al., 2006). All of the strains are Gram-negative, motile, non-spore-forming rods to short-rods, negative for arginine dihydrolase, ornithine decarboxylase, indole and $\mathrm{H}_{2} \mathrm{~S}$ production and grow in nutrient broth/agar. The carbon substrates tested and found not to be utilized by strain byr $23-80^{\mathrm{T}}$ are as follows: $N$-acetyl-D-galactosamine, acetoin, adonitol, D-arabinose, $(+)$-D-arabitol, $(+)$-L-arabitol, ascorbate, benzoate, $\gamma$-hydroxybenzoate, $\alpha$ hydroxybutyrate, $\gamma$-hydroxybutyrate, isobutyrate, trimethoxybenzoate, citrate, isocitrate, $\alpha$-cyclodextrin, dextrin, dulcitol, i-erythritol, formate, $(+)$-Dfucose, L-fucose, $\beta$-gentiobiose, D-gluconate, D-glucuronate, $(+)$-D-glucosamine, glycerol, glycogen, glycolate, glyoxylate, $m y o$-inositol, $\beta$-D-lactose, $\mathrm{D}$ lactose, lactulose, D-lyxose, malate, (+)-D-mannose, D-mannitol, (+)-D-melezitose, melibiose, D-psicose, (+)-D-raffinose, ribitol, D-ribose, shikimate, D-sorbitol, L-sorbose, D-tagatose, tartrate, turanose, xylitol and (+)-D-xylose, methanol, ethanol, propanol, 1,2-propanediol, butanol, 1,2-butanediol, 2,3-butanediol and ethylene glycol. Other carbon sources utilized by strain byr $23-80^{\mathrm{T}}$ are as follows: acetate, adipate, butyrate, $\beta$-hydroxybutyrate, caproate, hexanoate, caprylate, crotonate, D-erythrose, L-erythrulose, fumarate, glucose 1-phosphate, glucose 6-phosphate, isovalerate, lactate, malate, $N$ acetylglucosamine, oxaloacetate, propionate, protocatechuate, pyruvate, succinate and valerate. + , Positive; - , negative; $\mathrm{W}$, weak; ND, not determined.

\begin{tabular}{|c|c|c|c|c|c|c|c|}
\hline Characteristic & 1 & 2 & 3 & 4 & 5 & 6 & 7 \\
\hline Cell size $(\mu \mathrm{m})$ & $0.7-1.0 \times 1.5-2.0$ & $1.0 \times 3.0$ & $0.6-0.8 \times 1.8-2.2$ & ND & $0.6-0.7 \times 1.8-2.2$ & ND & $1.0 \times 1.6-3.0$ \\
\hline \multicolumn{8}{|l|}{ Growth characteristics: } \\
\hline $\mathrm{pH}$ range & $6.0-10.0$ & ND & $6.5-8.5$ & $6.5-8.5$ & $6.5-8.5$ & $6.5-8.5$ & $4.0-9.0$ \\
\hline pH optimum & $7.0-7.5$ & ND & $7.0-7.5$ & $7.0-7.5$ & $7.0-7.5$ & $7.0-7.5$ & $7.0-8.0$ \\
\hline Temp. range $\left({ }^{\circ} \mathrm{C}\right)$ & $4-30$ & $25-35$ & $10-45$ & $10-45$ & $10-45$ & $10-45$ & $4-30$ \\
\hline Temp. optimum $\left({ }^{\circ} \mathrm{C}\right)$ & 15 & 28 & $28-30$ & $28-30$ & $28-30$ & $28-30$ & 28 \\
\hline Flagellation & Polar or lateral & Polar or lateral & Lateral & Lateral & Lateral & Lateral & ND \\
\hline Voges-Proskauer test & - & - & - & - & + & - & - \\
\hline Methyl red test & - & - & + & - & - & - & - \\
\hline \multicolumn{8}{|l|}{ Hydrolysis of: } \\
\hline Starch & + & + & - & + & + & + & + \\
\hline Casein & + & ND & + & + & + & + & + \\
\hline Gelatin & - & + & + & + & + & + & + \\
\hline Nitrate reduction & + & - & + & + & + & - & - \\
\hline Urease & - & - & + & + & + & - & - \\
\hline Oxidase & - & + & + & + & - & + & $\mathrm{w}$ \\
\hline Catalase & $\mathrm{w}$ & + & + & + & + & + & + \\
\hline Milk coagulation & - & ND & - & - & - & - & ND \\
\hline Peptonization & - & + & - & - & - & - & ND \\
\hline \multicolumn{8}{|l|}{ Enzyme activities: } \\
\hline$\alpha$-Chymotrypsin & - & ND & ND & ND & ND & ND & - \\
\hline$\alpha$-Fucosidase & - & ND & ND & ND & $\mathrm{ND}$ & $\mathrm{ND}$ & - \\
\hline$\alpha$-Galactosidase & - & ND & + & + & + & + & - \\
\hline$\beta$-Galactosidase & - & ND & + & + & + & + & + \\
\hline$\beta$-Glucuronidase & - & ND & + & + & - & + & - \\
\hline$\alpha$-Glucosidase & + & ND & + & + & + & + & + \\
\hline$\beta$-Glucosidase & - & ND & + & + & + & + & - \\
\hline Lipase & - & ND & - & + & + & + & - \\
\hline $\mathrm{N}$-acetylglucosaminidase & - & ND & + & + & - & + & - \\
\hline Lysine decarboxylase & - & - & - & + & - & - & - \\
\hline \multicolumn{8}{|l|}{ Utilization of: } \\
\hline Glucose & + & - & + & + & + & + & + \\
\hline Sucrose & - & - & + & + & + & + & - \\
\hline D-Fructose & - & - & ND & ND & ND & ND & + \\
\hline D-Galactose & + & - & ND & ND & ND & $\mathrm{ND}$ & + \\
\hline L-Rhamnose & - & + & - & - & - & - & + \\
\hline Trehalose & - & - & - & $\mathrm{ND}$ & - & $\mathrm{ND}$ & - \\
\hline Malonate & - & + & - & ND & + & ND & ND \\
\hline Maltose & + & + & - & $\mathrm{ND}$ & - & $\mathrm{ND}$ & + \\
\hline Cellobiose & + & + & - & - & - & - & + \\
\hline L-Arabinose & - & + & - & - & - & - & - \\
\hline Galacturonate & - & + & - & - & - & - & ND \\
\hline Isolate source & Soil & Blood & Soil & Soil & Soil & Soil & Drinking water \\
\hline DNA G $+\mathrm{C}$ content $(\mathrm{mol} \%)$ & 65.3 & $62-67$ & 65.9 & 65.3 & 65.1 & 63.3 & 66.0 \\
\hline
\end{tabular}


Table 2. Cellular fatty acid content (\%) of strain byr23-80 and species of the genus Massilia

Strains: 1 , byr23-80 ${ }^{\mathrm{T}} ; 2$, M. timonae CIP $105350^{\mathrm{T}}$ (Lindquist et al., 2003); 3, M. dura CCTCC АB $204070^{\mathrm{T}} ; 4$, M. albidiflava CСТCС АB $204071^{\mathrm{T}}$; 5, M. plicata CCTCC AB $204072^{\mathrm{T}}$; 6. M. lutea CCTCC AB $204073^{\mathrm{T}}$ (data for strains 3-6 from Zhang et al., 2006); 7, M. aurea DSM $18055^{\mathrm{T}}$ (Gallego et al., 2006). tr, Trace.

\begin{tabular}{|lccccccc|}
\hline Fatty acid & $\mathbf{1}$ & $\mathbf{2}$ & $\mathbf{3}$ & $\mathbf{4}$ & $\mathbf{5}$ & $\mathbf{6}$ & $\mathbf{7}$ \\
\hline Saturated fatty acids & & & & & & & \\
$\mathrm{C}_{10: 0}$ & 0.5 & 1.0 & 0.6 & 1.3 & 1.4 & 0.5 & 0.4 \\
$\mathrm{C}_{12: 0}$ & 5.1 & 8.0 & 5.6 & 6.0 & 7.1 & 2.8 & 4.6 \\
$\mathrm{C}_{14: 0}$ & 2.1 & $\operatorname{tr}$ & 3.2 & 2.8 & 1.6 & 1.9 & 0.6 \\
$\mathrm{C}_{15: 0}$ & 1.2 & $\operatorname{tr}$ & - & - & - & - & - \\
$\mathrm{C}_{16: 0}$ & 21.4 & 25.0 & 25.5 & 22.8 & 25.1 & 22.8 & 36.8 \\
Unsaturated fatty acids & & & & & & & \\
$\mathrm{C}_{16: 1} \omega 7 c$ & 54.7 & 43.0 & 46.7 & 46.4 & 36.9 & 54.7 & 48.3 \\
iso-C $\mathrm{C}_{17: 1} \omega 9 c$ & 0.4 & - & - & - & - & 0.7 & - \\
$\mathrm{C}_{18: 1} \omega 7 c$ & 7.5 & 10.0 & 5.9 & 7.4 & 11.7 & 10.0 & 2.5 \\
Hydroxy fatty acids & & & & & & & \\
$\mathrm{C}_{10: 0} 3-\mathrm{OH}$ & 4.3 & 8.0 & 8.3 & 9.6 & 10.1 & 4.6 & 4.8 \\
$\mathrm{C}_{12: 0} 2-\mathrm{OH}$ & 1.4 & 3.0 & - & 0.7 & - & - & 1.9 \\
$\mathrm{C}_{14: 0} 2-\mathrm{OH}$ & - & - & 3.4 & 3.0 & 6.1 & 2.0 & - \\
\hline
\end{tabular}

The $\mathrm{G}+\mathrm{C}$ content of the genomic DNA was calculated from the mid-point value $\left(T_{\mathrm{m}}\right)$ of the melting profile (Øvreas et al., 2003) using the formula described by Mandel et al. (1970). Bacterial genomic DNA for the DNA G $+C$ content determination (and for the analysis of the $16 \mathrm{~S}$ rRNA gene sequence) was isolated using the method of Marmur (1961). The DNA G + C content was $65.3 \mathrm{~mol} \%$. The fatty acid profile, major respiratory quinone and DNA G $+\mathrm{C}$ content of strain byr $23-80^{\mathrm{T}}$ were all typical of those for species within the genus Massilia (Table 1).

For a higher resolution of the relationship between the novel strain and recognized species of the genus Massilia, the 16S rRNA gene sequence of byr $23-80^{\mathrm{T}}$ was amplified using primers $8 \mathrm{f}$ and 1492r (Lane, 1991) and subsequently sequenced using eight primers to cover the entire 16S rRNA gene (Gich et al., 2005). The sequence of strain byr $23-80^{\mathrm{T}}$ and recently described species were retrieved from the GenBank database using BLAST 2.0.4 (Altschul et al., 1997), imported into the ARB database and analysed using the ARB software package (Ludwig et al., 2004). The FAST ALIGNER (version 1.03) tool from the ARB software package was used for automated sequence alignment with previously aligned sequences from the ARB database. The alignment was subsequently checked and corrected manually on the basis of secondary structure information. Maximum-likelihood and neighbour-joining methods were employed to construct phylogenetic trees and the sequence similarities were calculated using the ARB distance matrix. The robustness of the tree topologies was evaluated by calculating bootstrap values (Felsenstein, 1985) using 1000 resamplings.
On the basis of the phylogenetic tree obtained (Fig. 3), strain byr23-80 $0^{\mathrm{T}}$ fell within the group of existing lineages of the genus Massilia. Similar results were obtained using the maximum-likelihood method (not shown). The closest described relative of strain byr $23-80^{\mathrm{T}}$ was $M$. aurea DSM $18055^{\mathrm{T}}$, for which a similarity value of $98.3 \%$ was calculated. The sequence similarities with respect to all other recognized Massilia species were $\leqslant 96.4 \%$. The $16 \mathrm{~S}$ rRNA gene sequence divergence between strain byr $23-80^{\mathrm{T}}$ and M. aurea DSM $18055^{\mathrm{T}}$ was within the range commonly used as a criterion for the separation of two bacterial species (Stackebrandt \& Goebel, 1994). Therefore DNA-DNA hybridization was carried out to evaluate whether strain byr $23-80^{\mathrm{T}}$ should be considered as a separate novel species. DNA-DNA hybridization was performed as described by De Ley et al. (1970), with the modifications described by Huß et al. (1983). The chromosomal DNA for DNA hybridization was isolated using a French pressure cell (Thermo Spectronic) and purified by means of chromatography on hydroxyapatite (Cashion et al., 1977). The similarity value between strain byr23-80 and M. aurea DSM $18055^{\mathrm{T}}$ was $20.1 \%$ and hence significantly lower than the threshold value of $70 \%$ that is commonly accepted for the definition of bacterial species (Wayne et al., 1987).

On the basis of the phenotypic and genotypic data presented, strain byr23-80 ${ }^{\mathrm{T}}$ represents a novel species within the genus Massilia, for which the name Massilia brevitalea sp. nov. is proposed.

\section{Description of Massilia brevitalea sp. nov.}

Massilia brevitalea (bre.vi.ta'le.a. L. adj. brevis short; L. fem. n. talea a rod; N.L. fem. n. brevitalea a short-rod, referring to the shape of cells).

Cells are Gram-negative, short rods that are $0.7-1.0 \mu \mathrm{m}$ wide and 1.5-2.0 $\mu \mathrm{m}$ long and motile by means of a single polar flagellum. Occasionally, cells with two or three polar or lateral flagella are observed. Cells are non-sporeforming, occur singly or in pairs (on 1:10-diluted HD medium at $15{ }^{\circ} \mathrm{C}$ after $36 \mathrm{~h}$ ) and are obligately aerobic. Colonies are circular, entire, convex, opaque and pale white to yellow. Cells grow chemo-organotrophically on diluted HD $(1: 10)$ agar and on nutrient agar. Oxidase-negative and weakly positive for catalase. The temperature range for growth is $4-30{ }^{\circ} \mathrm{C}$, with optimum growth occurring at $15{ }^{\circ} \mathrm{C}$. The $\mathrm{pH}$ range for growth is $6.0-10.0$, with optimum growth occurring at $\mathrm{pH} 7.0-7.5$. Can grow at $\mathrm{NaCl}$ concentrations of $\leqslant 2 \%(\mathrm{w} / \mathrm{v})$. Tweens 20 and 80 , casein and starch are hydrolysed, but gelatin is not hydrolysed. Positive for the following enzyme activities: acid phosphatase, alkaline phosphatase, $\alpha$-glucosidase, leucine arylamidase, naphthol-AS-BI-phosphohydrolase and urease. Distinguished from recognized species of the genus Massilia by an inability to hydrolyse gelatin and by the absence of $\alpha$-galactosidase and $\beta$-galactosidase activities. Tests negative for milk coagulation, indole production, 


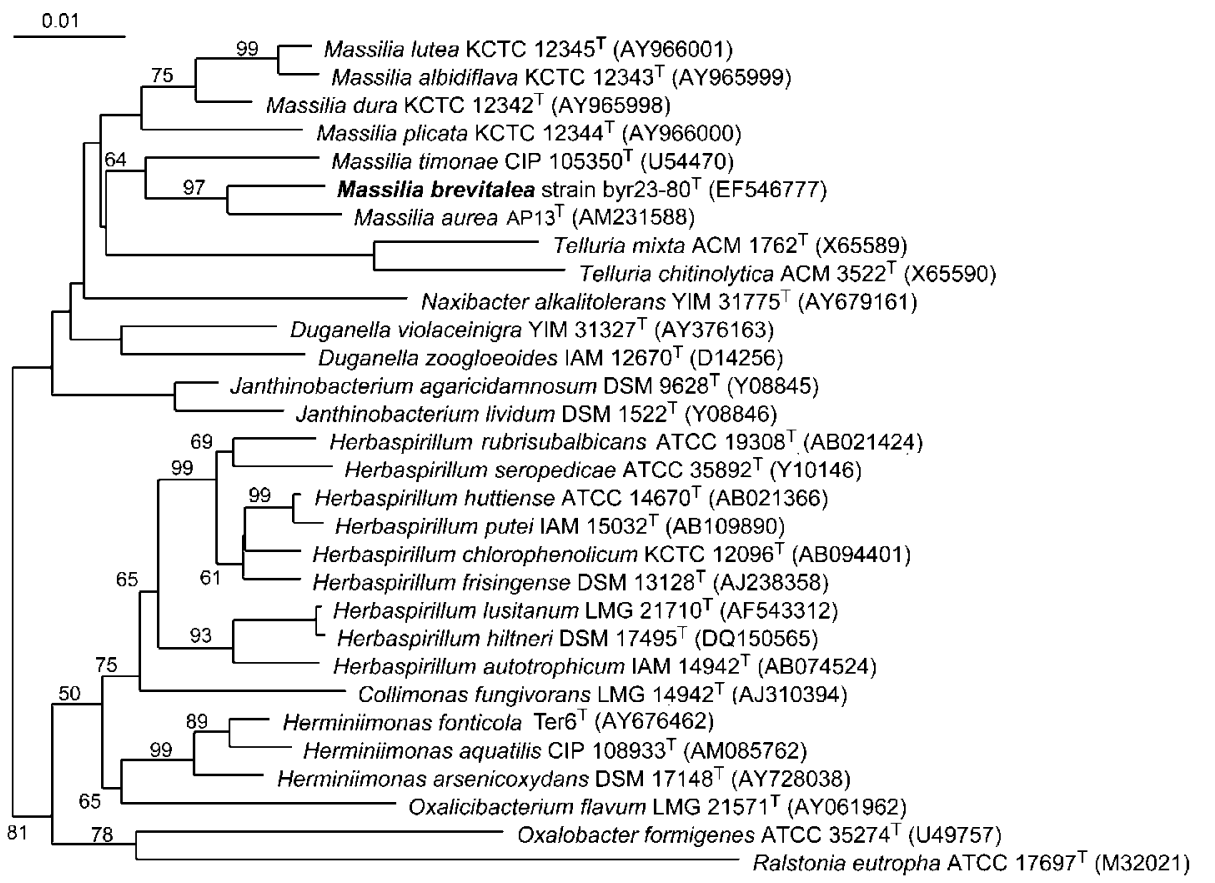

Fig. 3. Neighbour-joining phylogenetic tree, based on 16S rRNA gene sequences, showing the positions of strain byr23-80 $-80^{\top}$ and related bacteria within the family Oxalobacteraceae of the class Betaproteobacteria. The tree was rooted using Ralstonia eutropha ATCC $17697^{\top}$ as an outgroup. Bootstrap percentages (based on 1000 bootstrap resamplings) $>50 \%$ are given at branching points. Bar, 0.01 fixed point mutations per nucleotide.

hydrogen sulfide production and gives a negative result in the methyl red and Voges-Proskauer tests. Reduces $\mathrm{NO}_{3}^{-}$to $\mathrm{NO}_{2}^{-}$. Cellobiose, D-erythrose, L-erythrulose, Dgalactose, glucose, glucose 1-phosphate, glucose 6phosphate, maltose and $\mathrm{N}$-acetylglucosamine are utilized as sole carbon and energy sources. Growth occurs on acetate, adipate, butyrate, crotonate, hexanoate, caproate, caprylate, fumarate, $\beta$-hydroxybutyrate, isovalerate, $\alpha$ ketoglutarate, $\alpha$-ketoisohexanoate, $\alpha$-ketovalerate, lactate, malate, oxaloacetate, propionate, protocatechuate, pyruvate, succinate, valerate and (slowly) levulinate. $(+)$-LAlanine, L-alanylglycine, L-asparagine, $(+)$-L-asparaginate, $(+)$-L-cysteine, $(+)$-L-glutamate, $(+)$-L-isoleucine, $(+)$ L-leucine, $(+)$-L-lysine, $(+)$-L-phenylalanine, $(+)$-L-serine, (+)-L-threonine and (+)-L-tyrosine are utilized. Growth occurs on Casamino acids, yeast extract and peptone as complex organic substrates. The DNA G $+\mathrm{C}$ content is $65.3 \mathrm{~mol} \%$. Q-8 is the predominant respiratory quinone and the major cellular fatty acids are $\mathrm{C}_{16: 1} \omega 7 c$ and $\mathrm{C}_{16: 0}$. In addition, the diagnostic fatty acids $\mathrm{C}_{10: 0}$ $3-\mathrm{OH}$ and $\mathrm{C}_{12: 0} 2-\mathrm{OH}$ are present.

The type strain, byr $23-80^{\mathrm{T}}\left(=\mathrm{DSM} 18925^{\mathrm{T}}=\right.$ ATCC BAA$1465^{\mathrm{T}}$ ), was isolated from lysimeter soil from the Botanical Garden at the University of Bayreuth, Germany.

\section{Acknowledgements}

D.Z. is a recipient of a TPSDP (Technological and Professional Skills Development Sector Project) scholarship. The excellent technical assistance of Silvia Dobler is gratefully acknowledged. This work was supported by grants (Biolog/01LC0021A and 01LC0621C BMBF) from the Bundesministerium für Bildung, Wissenschaft, Forschung und Technologie to J. O.

\section{References}

Altschul, S. F., Madden, T. L., Schäffer, A. A., Zhang, J., Miller, W. \& Lipman, D. J. (1997). Gapped BLAST and PSI-BLAST: a new generation of protein database search programs. Nucleic Acids Res 25, 3389-3402.

Angle, J. S., McGrath, S. P. \& Chaney, R. L. (1991). New culture medium containing ionic concentrations of nutrients similar to concentrations found in the soil solution. Appl Environ Microbiol 57, 3674-3676.

Bodour, A. A., Wang, J. M., Brusseau, M. L. \& Maier, R. M. (2003). Temporal changes in culturable phenanthrene degraders in response to long-term exposure to phenanthrene in a soil column system. Environ Microbiol 5, 888-895.

Bruns, A., Hoffelner, H. \& Overmann, J. (2003). A novel approach for high throughput cultivation assays and the isolation of planktonic bacteria. FEMS Microbiol Ecol 45, 161-171.

Cashion, P., Holder-Franklin, M. A., McCully, J. \& Franklin, M. (1977). A rapid method for base ratio determination of bacterial DNA. Anal Biochem 81, 461-466.

De Ley, J., Cattoir, H. \& Reynaerts, A. (1970). The quantitative measurement of DNA hybridization from renaturation rates. Eur $J$ Biochem 12, 133-142.

Ederer, G. M., Chu, J. H. \& Blazevic, D. J. (1971). Rapid test for urease and phenylalanine deaminase production. Appl Microbiol 21, 545.

Felsenstein, J. (1985). Confidence limits on phylogenies: an approach using the bootstrap. Evolution 39, 783-791.

Gallego, V., Sánchez-Porro, C., García, M. T. \& Ventosa, A. (2006). Massilia aurea sp. nov., isolated from drinking water. Int J Syst Evol Microbiol 56, 2449-2453.

Gich, F. \& Overmann, J. (2006). Sandarakinorhabdus limnophila gen. nov., sp. nov., a novel bacteriochlorophyll $a$-containing, obligately aerobic bacterium isolated from freshwater lakes. Int J Syst Evol Microbiol 56, 847-854.

Gich, F., Schubert, K., Bruns, A., Hoffelner, H. \& Overmann, J. (2005). Specific detection, isolation, and characterization of selected, 
previously uncultured members of the freshwater bacterioplankton community. Appl Environ Microbiol 71, 5908-5919.

Huß, V. A. R., Festl, H. \& Schleifer, K. H. (1983). Studies on the spectrophotometric determination of DNA hybridization from renaturation rates. Syst Appl Microbiol 4, 184-192.

Khammar, N., Malhautier, L., Degrange, V., Lensi, R., Godon, J.-J. \& Fanlo, J.-L. (2005). Link between spatial structure of microbial communities and degradation of a complex mixture of volatile organic compounds in peat biofilters. J Appl Microbiol 98, 476-490.

Kuykendall, L. D., Roy, M. A., O’Neill, J. J. \& Devine, T. E. (1988). Fatty acids, antibiotic resistance, and deoxyribonucleic acid homology groups of Bradyrhizobium japonicum. Int J Syst Bacteriol 38, 358-361.

La Scola, B., Birtles, R. J., Mallet, M.-N. \& Raoult, D. (1998). Massilia timonae gen. nov., sp. nov., isolated from blood of an immunocompromised patient with cerebellar lesions. J Clin Microbiol 36, 2847-2852.

Lane, D. J. (1991). 16S/23S rRNA sequencing. In Nucleic Acid Techniques in Bacterial Systematics, pp. 115-175. Edited by E. Stackebrandt \& M. Goodfellow. Chichester: Wiley.

Lányí, B. (1987). Classical and rapid identification methods for medically important bacteria. Methods Microbiol 19, 1-67.

Lindquist, D., Murrill, D., Burran, W. P., Winans, G., Janda, J. M. \& Probert, W. (2003). Characteristics of Massilia timonae and Massilia timonae-like isolates from human patients, with an emended description of the species. J Clin Microbiol 41, 192-196.

Ludwig, W., Strunk, O., Westram, R., Richter, L., Meier, H., Yadhukumar, Buchner, A., Lai, T., Steppi, S. \& other authors (2004). ARB: a software environment for sequence data. Nucleic Acids Res 32, 1363-1371.

Mandel, M., Igambi, L., Bergendahl, J., Dodson, M. L. \& Scheltgen, E. (1970). Correlation of melting temperature and cesium chloride buoyant density of bacterial deoxyribonucleic acid. J Bacteriol 101, 333-338.

Marmur, J. (1961). A procedure for the isolation of deoxyribonucleic acid from microorganisms. J Mol Biol 3, 208-218.

Miller, L. T. (1982). A single derivatization method for bacterial fatty acid methyl esters including hydroxy acids. J Clin Microbiol 16, $584-586$.
Øvreas, L., Daae, F. L., Torsvik, V. \& Rodríguez-Valera, F. (2003). Characterization of microbial diversity in hypersaline environments by melting profiles and reassociation kinetics in combination with terminal restriction fragment length polymorphism (T-RFLP). Microb Ecol 46, 291-301.

Padmanabhan, P., Padmanabhan, S., DeRito, C., Gray, A., Gannon, D., Snape, J. R., Tsai, C. S., Park, W., Jeon, C. \& Madsen, E. L. (2003). Respiration of ${ }^{13} \mathrm{C}$-labeled substrates added to soil in the field and subsequent 16S rRNA gene analysis of ${ }^{13} \mathrm{C}$-labeled soil DNA. Appl Environ Microbiol 69, 1614-1622.

Skerman, V. B. D. (1967). A Guide to the Identification of the Genera of Bacteria, 2nd edn. Baltimore: Williams \& Wilkins.

Spurr, A. R. (1969). A low-viscosity epoxy resin embedding medium for electron microscopy. J Ultrastruct Res 26, 31-43.

Stackebrandt, E. \& Goebel, B. M. (1994). Taxonomic note: a place for DNA-DNA reassociation and $16 \mathrm{~S}$ rRNA sequence analysis in the present species definition in bacteriology. Int J Syst Bacteriol 44, 846-849.

Tindall, B. J. (1990a). A comparative study of the lipid composition of Halobacterium saccharovorum from various sources. Syst Appl Microbiol 13, 128-130.

Tindall, B. J. (1990b). Lipid composition of Halobacterium lacusprofundi. FEMS Microbiol Lett 66, 199-202.

Wayne, L. G., Brenner, D. J., Colwell, R. R., Grimont, P. A. D., Kandler, O., Krichevsky, M. I., Moore, L. H., Moore, W. E. C., Murray, R. G. E. \& other authors (1987). International Committee on Systematic Bacteriology. Report of the ad hoc committee on reconciliation of approaches to bacterial systematics. Int J Syst Bacteriol 37, 463-464.

Zhang, Y.-O., Li, W.-J., Zhang, K.-Y., Tian, X.-P., Jiang, Y., Xu, L.-H., Jiang, C.-L. \& Lai, R. (2006). Massilia dura sp. nov., Massilia albidiflava sp. nov., Massilia plicata sp. nov. and Massilia lutea sp. nov., isolated from soils in China. Int J Syst Evol Microbiol 56, 459-463.

Zul, D., Denzel, S. \& Overmann, J. (2007). Effects of plant biomass, plant diversity and water content on bacterial communities in soil lysimeters: implications for the determinants of bacterial diversity. Appl Environ Microbiol 73, 6916-6929. 